\title{
EFFECT OF DIETS INOCULATED WITH LACTOBACILLUS PLANTARUM DSMZ 20191 ON GROWTH PERFORMANCE AND QUALITY PARAMETERS OF NILE TILAPIA (OREOCHROMIS NILOTICUS) FINGERLINGS
}

\author{
G.D.I. Hassanen ${ }^{1}$; D.H. Hanafy ${ }^{2}$; M.A. Ibrahim ${ }^{3}$ and Salha S.M. Gaber ${ }^{4}$ \\ ${ }^{1}$ Dep. of Fisheries and Aquaculture, Faculty of Environmental Agricultural Sciences, El-Arish, Suez \\ Canal Univ., Egypt. \\ ${ }^{2}$ Fish Nutrition Lab., Aquaculture Division, and ${ }^{3}$ Fish Processing Technology, Fisheries Division, \\ National Institute of Oceanography and Fisheries, Cairo, Egypt.
}

${ }^{4}$ Dep. of Botany and Microbiology, Faculty of Science, Suez Univ., Egypt.

(Received 28/6/2015, accepted 12/8/2015)

\section{SUMMARY}

$\mathrm{T}$ This study was designed to investigate the effect of diets inoculated with antifungal metabolites of Lactobacillus Plantarum DSMZ 20191 on growth performance and quality parameters of the Nile Tilapia fingerlings (Oreochromis niloticus). Fish diets; animal, plant and mixed were sprayed with the antifungal metabolites levels of (1,2,3,4 and $5 \mathrm{ml} / 100 \mathrm{~g}$ for each diet); packed using polyethylene bags and stored under room temperature for 90 days. Tilapia fingerlings were fed on diets inoculated with $5 \%$ of the metabolites extract for 180 days. Water quality, growth performance (GP) parameters and quality criteria of Tilapia treatments were determined. Results showed that L. Plantarume specially at $5 \%$ had a high activity against molds contaminated animal fish diet, moderate in plant and low in mixed diets. Also, the growth promoters (probiotic) improved GP and reduced mortality rate, mixed and plant diets increased weight gain (WG) while animal diet gave the best protein efficiency ratio (PER).Concerning quality criteria, the metabolites of Lb. plantarum could slightly decrease the $\mathrm{pH}$ value in fish fed on treated diets compared with control sample, while total volatile bases (TVB), trimethylamine (TMA) and thiobarbituric acid (TBA) values of fish fed on mixed protein diet were lowered compared with the control sample. Finally, it could be concluded that the inoculated fish diets by metabolites improved the growth rate, chemical composition and quality criteria of Tilapia fish flesh compared with control sample and this leads to extend shelf-life for these fish.

Keywords: Lactobacillus Plantarum, different protein sources diets, quality criteria, the Nile tilapia (Oreochromisniloticus).

\section{INTRODUCTION}

Studies on the effect of lactic acid bacteria (LAB) on fungi are complicated by the fact that some fungi are sensitive to the normal by-products of LAB metabolism, most notably lactic and acetic acids (Bonesteroo et al., 1993). Penicillum and Aspergillus sp. have been reported as spoilage organisms during storage of food and feeds and Fusarium sp. are often found on cereal grains, where they might produce mycotoxins (Filtenborg et al., 1996). Aflatoxins, part of a large group called mycotoxins, are toxic substances produced as a result of mold growing on grain, feedstuff and other foods.Mycotoxigenic fungi such as Fusarium and Penicillium are serious hazard for human health (Dalie et al., 2009). Filamentous molds and yeasts are common spoilage organisms of food products as stored crops, bread and feed such as hay and silage (Bullerman, 1977), and between 5 and 10\% of the world's food productions lost is due to fungal detonation (Pitt and Hocking, 1999). During the last few years there has been a growing interest in biopreservation to 


\section{Hassanen et al.}

prevent spoilage and extend the shelf life of foods (Stiles, 1996). Lactic acid bacteria (LAB) have a long history in preserving foods from .spoilage microorganisms, they are commonly used in food fermentation, many produce several metabolites with beneficial health effects and are generally recognized as safe. Nowadays, the application of LAB with the simultaneous control of factors that affect the fungal growth can help to minimize food spoilage (Muhialdin et al., 2013). Therefore, the effect of antifungal metabolites produced by Lactobacillus plantarum DSMZ 20191 on molds contaminated plant, animal and mixed fish diets and its role in improving the growth performance and quality criteria of fingerlings were investigated.

\section{MATERIALS AND METHODS}

\section{Culture and metabolites extraction:}

Bacterial strain (Lactobacillus plantarumDSMZ 20191) was obtained from Food Science Department, Faculty of Agriculture, Ain Shams University. The culture was activated on MRS broth medium. This strain was cultivated on $2000 \mathrm{ml}$ of de Man, Rogosa and Sharpe (MRS) (de Man et al., 1960) broth medium, divided into $20 \mathrm{ml}$ flasks, each flask contained $100 \mathrm{ml}$, inoculated with $2 \%$ of the bacterial cells suspension, and then incubated at $32^{\circ} \mathrm{C}$ for $48 \mathrm{~h}$. After that, a cell free extract was obtained by centrifugation at 10.000 rpm at $4^{\circ} \mathrm{C}$ for $20 \mathrm{~min}$., the extract was adjusted at $\mathrm{pH} 7.0$ by $1 \mathrm{M} \mathrm{NaOH}$ to exclude the effect of organic acids. The extract was filtrated through a $0.2 \mathrm{~mm}$ pore size cellulose acetate filter (Schillliner et al., 1989), and dialyzed for $12 \mathrm{~h}$.

\section{Determination of the metabolites most active concentration:}

The activity of the different concentration of the antifungal metabolites (1-2-3-4 and 5\%) obtained from Lb. plantarum DSMZ 20191 were tested and used for inhibition of fungal growth in different fish diets (animal- plant and mixed). The concentration of 5\% was selected for its good activity not only in preservation of the fish diets but also for its probiotic effect in promotion of growth rate and also improvement of fish quality, so fish diet supplemented with 5\% of the antifungal metabolites for feeding of tilapia fingerlings during the breeding period to was used illustrate the probiotic effect and how it improve the fish health.

\section{Experimental diets:}

Three diets were formulated (Table 1); the first diet was the dietary protein derived mostly from animal sources (fish meal, meat, bone meals and poultry by product meal). The second diet was derived from plant sources (soybean meal, sunflower meal and corn gluten meal). Finally the third diet was a mixture of animal and plant. All ingredients were prepared by successive grinding through a commercial feed grinder (1/16 mesh). 5\% antifungal supernatant was added to all diets. Then diets were mechanically mixed by horizontal mixer, the feed mixture was processed by California pellet meal (CPM) machine. The pellets were $2 \mathrm{~mm}$ diameter $4 \mathrm{~mm}$ length. All diets were isonitrogenous $(30 \pm 0.43)$ and isocaloric $(\mathrm{GE}=4102 \pm 36)$. All diets were inoculated by different levels $(1,2,3,4$ and $5 \mathrm{ml} / 100 \mathrm{~g}$ diet $)$ and then stored at $4^{\circ} \mathrm{C}$. The results showed that diets treated with $5 \%$ antifungal metabolites and stored for 90 days gave the best results in inhibition of fungi and hence these diets were used for tilapia feeding. Amino acid of the experimental diets were determined by using amino acid analyzer according to methods described by Ibrahim (1974), tryptophan was determined calorimetrically in alkaline hydrolysate according to methods described by Blauth et al. (1963). Table (2) show the essential amino acid of the experimental diets.

\section{Fish samples:}

Juvenile Nile Tilapia (Oreochromsniloticus)samples $(30 \pm 1.73 \mathrm{~g}$ weight and $10 \pm 1.04 \mathrm{~cm}$ length) were obtained from fish farm of El-Kanater El-Khayria Fish Research Station belonging to the National Institute of Oceanography and Fisheries(NIOF), transferred to experimental concrete ponds and fish stock rate was 12 unit $\mathrm{m}^{3}$. Fish samples were acclimatized for ten days and then were fed using $3 \%$ of the body weight per day. The daily ration was offered two times a day; $9 \mathrm{AM}$ and $3 \mathrm{PM}$ in two equal portions. The experimental diets were fed to 3 replicates groups. Fish weights of each treatment were measured biweekly intervals. 
Table (1): Formulation and proximate composition of the experimental diets containing animal and /or plant protein sources (means $\pm \mathrm{SE}$ ).

\begin{tabular}{lccc}
\hline Ingredient $(\mathrm{g} / 100 \mathrm{~g})$ & $\begin{array}{c}\text { Diet } 1 \\
\text { Animal protein }\end{array}$ & $\begin{array}{c}\text { Diet } 2 \\
\text { Plant protein }\end{array}$ & $\begin{array}{c}\text { Diet } 3 \\
\text { Combined }\end{array}$ \\
\hline Fish meal (62\% CP) & 9 & 0 & 5 \\
Meat and bone meal $(52 \% \mathrm{CP})$ & 10 & 0 & 5 \\
Soybean meal (44\% CP) & 0 & 40 & 17 \\
Sunflower cake (33\% CP) & 0 & 17 & 10 \\
Corn glutein meal (60\% CP) & 0 & 8 & 3 \\
Poultry by product meal (60\% CP) & 26 & 0 & 13 \\
Wheat bran (12.5\% CP) & 25.8 & 18 & 26.8 \\
Yellow corn meal (7.5\% CP) & 18 & 6.8 & 10 \\
Sunflower oil & 0 & 5.4 & 2.6 \\
Linseed oil & 5.4 & 0 & 2.6 \\
1Vitamins \& Minerals premix & 4 & 4 & 4 \\
Lysine and Methionine & 0.2 & 0.2 & 0.2 \\
Carboxy-methyl cellulose & 1.6 & 1.6 & 1.5 \\
Total & 100 & 100 & 100 \\
Proximate analysis ( on dry matter basis ) & & & \\
Dry matter (DM) & $96.77 \pm 0.39$ & $97.08 \pm 0.69$ & $96.55 \pm 0.57$ \\
Crude protein (CP) & $30.88 \pm 0.77$ & $30.30 \pm 0.88$ & $30.11 \pm 0.67$ \\
Ether extract (EE) & $6.90 \pm 0.55$ & $6.44 \pm 0.57$ & $6.88 \pm 0.64$ \\
Ash content & $8.93 \pm 0.17$ & $9.30 \pm 0.15$ & $9.61 \pm 0.11$ \\
Crude fiber & $9.69 \pm 0.11$ & $10.09 \pm 0.32$ & $9.91 \pm 0.21$ \\
${ }^{2}$ NFE & $43.60 \pm 0.40$ & $43.87 \pm 0.48$ & $43.49 \pm 0.41$ \\
${ }^{3}$ Gross energy (Kcal/kg) & 4140.77 & 4075.33 & 4090.98 \\
P/E ratio & 74.58 & 74.35 & 736 \\
\hline
\end{tabular}

Table (2): Concentrations of essential amino acids (\% of dietary protein) in diets containing animal and /or plant protein sources.

\begin{tabular}{lcccc}
\hline Amino acids & Requirements & $\begin{array}{c}\text { Diet } 1 \\
\text { Animal protein }\end{array}$ & $\begin{array}{c}\text { Diet } 2 \\
\text { Plant protein }\end{array}$ & $\begin{array}{c}\text { Diet 3 } \\
\text { Combined }\end{array}$ \\
\hline Arginine & $4.2(1.18)$ & 5.78 & 6.838 & 6.438 \\
Histidine & $1.72(0.48)$ & 2.303 & 2.524 & 2.437 \\
Isoleucine & $3.11(0.87)$ & 3.560 & 4.244 & 3.921 \\
Leucine & $3.39(0.95)$ & 7.430 & 7.522 & 7.827 \\
Lysine & $5.12(1.43)$ & 6.026 & 6.584 & 5.491 \\
Methionine & $2.68(0.75)$ & 2.815 & 1.047 & 3.207 \\
Cystine & 0.53 & 2.475 & 1.751 & 1.491 \\
Phynile alanine & $3.75(1.05)$ & 3.887 & 4.846 & 4.327 \\
Tyrosine & 1.79 & 2.838 & 3.077 & 2.961 \\
Threonine & $3.75(1.05)$ & 2.885 & 3.675 & 3.291 \\
Tryptophan & $1.00(0.28)$ & 1.073 & 1.901 & 1.621 \\
Valine & 2.80 & 4.669 & 4.984 & 4.872 \\
Total & 32.84 & 45.741 & 48.993 & 47.884 \\
\hline
\end{tabular}

Santiago \& Lovel (1988).

\section{Analytical methods:}

Water quality parameters:

Physico-chemical characteristics (temperature, $\mathrm{pH}$ value, ammonia, nitrate and nitrite) of ponds water were determined as mentioned by APHA (1992). 
Table (3): Physico-Chemical characteristics of water quality parameters during the experimental period (6 months) (Means $\pm \mathrm{SE})$.

\begin{tabular}{lccc}
\hline Parameters & $\begin{array}{c}\text { Diet } 1 \\
\text { Animal protein }\end{array}$ & $\begin{array}{c}\text { Diet } 2 \\
\text { Plant protein }\end{array}$ & $\begin{array}{c}\text { Diet 3 } \\
\text { Combined }\end{array}$ \\
\hline Water Temperature $\left({ }^{\circ} \mathrm{C}\right)$ & $25.10 \pm 1.27$ & $25.81 \pm 2.11$ & $25.62 \pm 1.59$ \\
pH value & $7.52 \pm 0.18$ & $7.32 \pm 0.21$ & $7.68 \pm 0.09$ \\
Dissolved oxygen $(\mathrm{DO}) \mathrm{mg} / \mathrm{L}$. & $6.68 \pm 1.33$ & $6.81 \pm 1.17$ & $6.77 \pm 1.54$ \\
Ammonium $\left(\mathrm{NH}_{3}\right) \mathrm{mg} / \mathrm{L}$. & $0.30 \pm 0.05$ & $0.27 \pm 0.07$ & $0.29 \pm 0.02$ \\
Nitrite $\left(\mathrm{NO}_{2}\right) \mathrm{mg} . / \mathrm{L}$ & $0.33 \pm 0.01$ & $0.37 \pm 0.06$ & $0.39 \pm 0.04$ \\
Nitrate $\left(\mathrm{No}_{3}\right) \mathrm{mg} / \mathrm{L} . \quad$ & $0.36 \pm 0.03$ & $0.31 \pm 0.06$ & $0.34 \pm 0.05$ \\
\hline
\end{tabular}

*All values are mean of triplicate feeding groups.

\section{Growth performance parameters:}

Live weight, gain in live weight, specific growth rate, feed consumption, feed conversion, protein efficiency ratio (PER), protein retained and lipid retained were collected and calculated throughout the whole experimental period (180 days).Moisture, crude protein $(\mathrm{N} \times 6.25)$, fat, ash and fiber content were determined according to (AOAC, 2000) for diets and fish samples.

\section{Quality criteria:}

The $\mathrm{pH}$ value, total volatile bases nitrogen (TVB-N) content and thiobarbituric acid (TBA) value for adult fish samples were measured as the methods described by Pearson (1991), while trimethylamine nitrogen (TMA-N) content was determined according to the procedures of AOAC (2000).

\section{Statistical analysis:}

Analysis of variance, Duncan test and the estimation of least significant differences were carried out according to Snedecor and Cochran (1974).

\section{RESULTS AND DISCUSSION}

Figure (1) illustrates the most active metabolites concentrations of the lb. platarum DSMZ 20191 during different storage periods at dilution of 10-2 (from the results of the previous trial No. 1; under press). Fig. 1 illustrated that, concentration of 5\% of the antifungal metabolites obtained from Lb. plantarum DSMZ 20191 gave the most active results for inhibition of fungal growth at concentration of 10-2 in different fish diets during 90 days of storage. In animal protein source (fish meal)the antifungal activity recorded $100 \%$ which means complete inhibition for fungal growth in fish diet during 60 days of storage and then, the activity lowered to $92 \%$ at 75 days, then $88 \%$ at 90 days. For plant protein source the antifungal activity was $85 \%$ at zero time, then rose to $89 \%$ during 30 days and gradually lowered to $(84,81,78$, and $75 \%)$ at the end of the storage period. Finally in mixed protein sources the activity recorded $88 \%$ at zero time, then up to $90 \%$ after that down to $21 \%$ after 45 days and again lowered to 80 and $74 \%$ at 90 days of storage. Due to these results we only used fish diet inoculated with 5\% of the antifungal metabolites of Lb. plantarum DSMZ 20191 in trial 2 for feeding of Tilapiafingerlings during the whole breeding period to demonstrate the probiotic effect on growth rate of fingerlings and also its effect on chemical composition of fish muscles.Lactic acid bacteria (LAB) are known to produce different antimicrobial compounds and are important in the biopreservation of food and feed (Messens and de Vuyst, 2002) and (lindgren, 1990). Lavermicocca et al. (2000) reported production of the antifungal compounds phenyllactic acid and 4-hydroxyphenyllactic acid by sourdough Lactobacillus plantarum strain. According to (Sib et al., 2013), administration of Lb. plantarum VSG3 for 60 days of feeding had significant effects $(\mathrm{P} \leq 0.05)$ on the specific growth rate (SGR) and feed utilization efficiency of fish. Dietary administration of Lb. plantarum significantly increased the serum lysozyme and alternative complement pathway (ACP) activities, phagocytosis and also increased survival rate (77.7). 


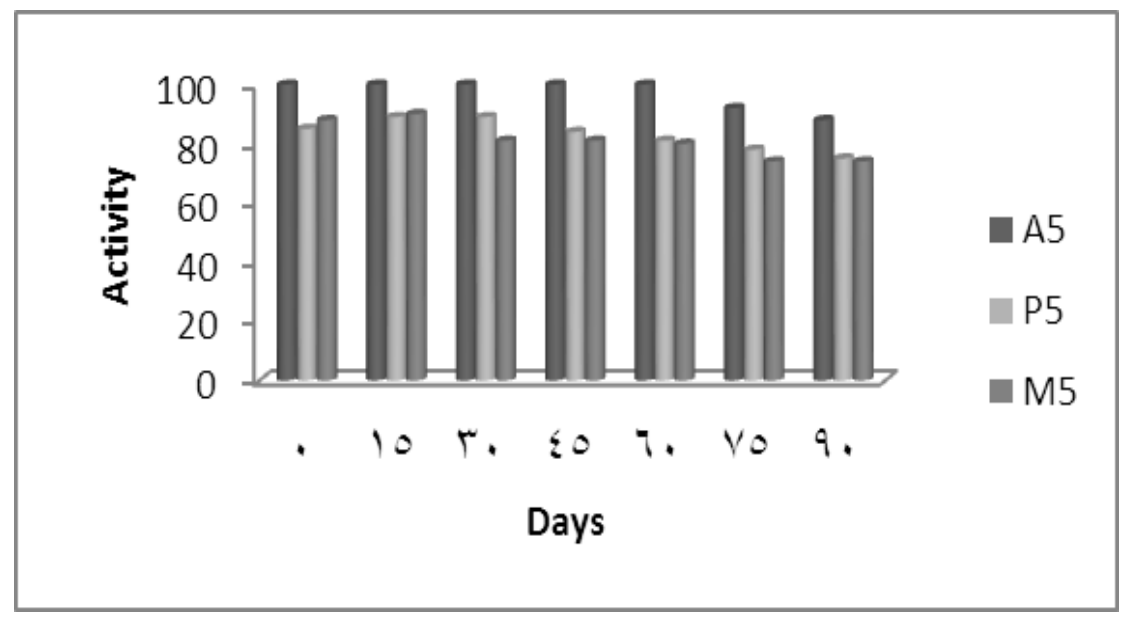

Fig. (1): The activity $\backslash$ days of the antifungal metabolites $(1,2,3,4$ and $5 \%)$ obtained from $L b$. plantarum DSMZ 20191. Where: A5: Animal fish diet (5\% of antifungal metabolites), P5: Plant diet (5\%) and M5: Mixed fish diet (5\%).

Table (4) shows the average of feed efficiency for investigated diets. The average of feed efficiency (FE) for group 1, 2 and 3 were $0.44,0.37$ and 0.42 , respectively. The analysis of variance of data showed that differences in this trait among the groups were significant for the favor or animal protein diet (diet 1) and combined protein (diet 3). These results may indicate that diet containing animal protein gave the best (FE) value during the experimental period. FE for the fish fed plant protein diet (diet 2) and combined protein diets (3) was significantly lower than that of in animal protein diet. However, the diet containing combined protein sources was better than diet containing plant protein. The palatability of tested diet based on feed consumption and feed conversion ratio, was of interest, since a low intake of feed containing high levels of some vegetable foodstuff has been reported by several authors (Robaina et al., 1995 and Roselund, 1986). This observation seems to be associated with high sensitivity of fish to the organoleptic properties of their diet (Bone and Marshall, 1982) in juvenile Chinook salmon. Extremely low feed intake levels of diet 2 (Plant protein only) was observed in this study which containing $40 \%$ soybean and $17 \%$ sunflower cake and $8 \%$ corn gluten meal were related to the poor palatability of these products. These results are in agreement with those findings by Hajen et al. (1993) and Hassanen (1998). The poor palatability of soybean meal has also been reported in other fish species (Fowler, 1980). Diet containing animal protein (Fish meal and meat and bone meal) was likely superior because of high digestibility and well-balanced indispensable amino acid composition.

The result of the feed intake and feed conversion ratio that enhanced is due to probiotic effect of LAB added to the diets by concentration of 5\% was better with blackberries protein diet containing mixed (animal + vegetable), followed by the diet containing animal protein and then a bush vegetable protein and that during the period of the experiment (180 days). These results are in agreement with that reported by Abdel-Hakim $e t$ al. (2006) who showed that the Nile tilapia diets supplemented with Biogen, Biovit or Bioaction improved feed intake and feed conversion ratio compared with control diet. The results showed also that addition of growth promoters, the antifungal metabolites to the diet which contained a mixture of protein sources (animal + plant) gave $100 \%$ survival rate for the fish, while it was $94.44 \%$ of diet contained animal protein sources however; it was $91.7 \%$ of plant diet (Table 4). High survival rate is due to use of growth promoters (probiotic) that lead to produce various beneficial effects as enhancement of growth performance and reduction in mortality as reported by Chang and Liu (2002); Abo-State (2005); Keysami et al. (2007); Eid and Mohamed (2008). With respect to total weight gain and SGR (\%/day), the highest gain in weight was observed in fish fed combined protein diet (diet 3 - Table 4) being significantly higher than that of fish fed animal protein was obtained by the group fed on plant protein diet (diet 2). Protein utilization parameter calculated as protein efficiency ratio (PER) obtained on testing the different diets (Table4), revealed greater value for diet containing animal protein followed by the combined protein diet and then followed by the diet containing plant protein. As show in Table (4) results of energy intake have almost the same trends as in feed intake. The imbalance between isoleucine and leucine in the plant protein diet (Table 2) was more likely to be responsible 


\section{Hassanen et al.}

for the slightly lower protein utilization of plant protein than animal or/and combined protein diets. Hassanen (1997) showed that a mixture of protein sources with an amino acid profile was similar to that of requirement significantly improved the growth of gilthead sea bream ( $S$. aurata). In general, growth performance parameters of Nile tilapia ( $O$. nilioticus) were improved by supplementing the fingerlings diets with probiotic incorporated at the higher levels. These results are in accordance with findings by Jena et al. (1996) who indicated that Catla and Rohu fry fed on the experimental diet with a probiotic supplement showed significant increases in length and weight at different stages of the experiment compared with those fed on the control diet. In this connection, Bogut et al. (1998) studied the influence of probiotic (Streptococcus faecium M74) on growth and content of intestinal microflora in carp (Cyprinuscarpio). Fish was fed on subjected to two experimental diets either containing zero (control) or 1gm probiotic/100 kg feed from July to August, 1996. The experimental group had higher average individual weight by (12.42\%), better feed conversion (by $17.37 \%$ ) and higher specific growth rate (by 10.20\%) compared to the control group. Moreover, E. coli was completely eliminated from the intestine after 14 days of probiotic feeding.

Table (4): Effect of feeding animal and /or plant protein sources on growth performance and feed utilization efficiency.

\begin{tabular}{lccc}
\hline Items & $\begin{array}{c}\text { Diet 1 } \\
\text { Animal protein }\end{array}$ & $\begin{array}{c}\text { Diet } 2 \\
\text { Plant protein }\end{array}$ & $\begin{array}{c}\text { Diet 3 } \\
\text { Combined }\end{array}$ \\
\hline Initial bodyweight $(\mathrm{g})$ & $30.29 \pm 1.67$ & $30.02 \pm 1.84$ & $30,12 \pm 1.69$ \\
Initial body length(cm) & $10.91 \pm 0.58$ & $11.17 \pm 0.51$ & $11.04 \pm 0.73$ \\
Final body weight (g) & $217.85^{\mathrm{b}} \pm 4.7$ & $183.47^{\mathrm{c}} \pm 4.3$ & $234.45^{\mathrm{a}} \pm 3.7$ \\
Final body length (cm ) & $21.42 \pm 0.66$ & $19.39 \pm 0.36$ & $22.53 \pm 0.45$ \\
Weight gain (g/fish ) 1 & $187.56^{\mathrm{b}} \pm 4.11$ & $153.45^{\mathrm{c}} \pm 3.98$ & $204.33^{\mathrm{a}} \pm 4.07$ \\
Daily gain (g/fish/day) & $1.36 \pm 0.07$ & $1.11 \pm 0.05$ & $1.48 \pm 0.08$ \\
Specific growth rate(SGR\%/day) & $1.06 \pm 0.02$ & $1.19 \pm 0.02$ & $1.24 \pm 0.03$ \\
Condition factor (K) & $3.49 \pm 0.21$ & $3.20 \pm 0.13$ & $3.68 \pm 0.16$ \\
Feed conversion ratio (FCR) & $2.21 \pm 0.07$ & $2.52 \pm 0.09$ & $2.05 \pm 0.06$ \\
Survival rate (\%) & 94.44 & 91.7 & 100 \\
Feed consumption( Fc) & $428.15 \pm 2.14$ & $417.15 \pm 2.22$ & $490.09 \pm 2.35$ \\
Protein efficiency ratio(PER) & $1.42 \pm 1.8$ & $1.21 \pm 1.5$ & $1.38 \pm 1.7$ \\
Experimental period (days) & 180 & 180 & 180 \\
Protein intake (g ) & $11.024 \pm 0.25$ & $10.532 \pm 0.31$ & $12.317 \pm 0.28$ \\
Energy intake (Kcal/g) & 1478.25 & 1416.58 & 1670.76 \\
\hline
\end{tabular}

$*$ All values are mean of triplicate feeding groups.

1-Weight gain $(\%)=$ Final weight /Initial weight $x 100 ; 2-(\% / d)=($ InW2 - InW1/T2 - T1 $) \times 100 ; 3-$ Food conversion ratio $=$ food fed $(\mathrm{g})$ /live weight gain $(\mathrm{g}) ; 4$-Protein efficiency ratio = live weight gain $(\mathrm{g}) /$ protein fed $(\mathrm{g}) ; 5$-Condition factor $=W_{2} / L^{3}$

The results of Table (5) showed that the whole fishes were characterized by high moisture ranged between $24.97-25.13 \%$ in all treatments compared with untreated sample $(25.43 \%)$. Total crude protein ranged from $64.11 \%$ to $65.11 \%$, while it was $81.23 \%$ control sample. Therefore, it could be found that the effect of different protein sources (animal, plant and combined protein) diets didn't markedly affect tilapia flesh. High protein for fish fed on combined protein diet (diet 3), probably increased the greater weight gain compared to the other protein sources. Lipid ranged between $17.82-18.15 \%$ of the three treatments, while it was $18.48 \%$ in control sample. Ash content ranged $17.02 \%$ to $17.74 \%$ compared with $18.24 \%$ of control. Based on our results, it could be found that the effect of different protein sources in the diets didn't appear on the chemical composition of tilapia flesh. The present results are localized with those finding by several studies (Tongnuanchan et al., 2011; Al-Souti et al., 2012 and Abdallah, 2013). In addition, results showed that LAB recorded superior dry matter and protein content in fish muscle which fed on diets containing combined protein sources compared with groups fed on plant and animal protein. As presented in the same Table (table 5) LAB increased lipid content in the fish muscle which fed on diet containing plant protein only. On the other hand, LAB decreased ash content in muscles of fish fed on animal protein diets. In this respect Abo State (2005) reported that incorporation of Biogen probiotic in diets of Nile tilapia (O. niloticus) at $2 \mathrm{~g} / \mathrm{Kg}$ diet increased crude protein content in whole bodies while decreased lipid. The same author added that lecture probiotic insignificantly increased crude protein content in fish bodies when fed to Tilapia fingerlings at 
$1 \mathrm{~g} / \mathrm{Kg}$ diet level, meanwhile, this level decreased lipid content and increased ash contents significantly $(P \leq$ 0.05). Abdel Hamid et al. (2000) showed that the highest ash content of fish carcass resulted from feeding dry yeasture and lactosac. They added that the highest lipid content $(31.99 \%)$ was found in fish fed the diet with yeasture at $2 \mathrm{~g} / \mathrm{Kg}$.

Table (5): Composition of the whole fish feed on the experimental diets (g/100 dry weight).

\begin{tabular}{lcccc}
\hline Parameters & $\begin{array}{c}\text { Untreated } \\
\text { Diet (Control) }\end{array}$ & $\begin{array}{c}\text { Diet 1 } \\
\text { Animal protein }\end{array}$ & $\begin{array}{c}\text { Diet 2 } \\
\text { Plant protein }\end{array}$ & $\begin{array}{c}\text { Diet 3 } \\
\text { Combined }\end{array}$ \\
\hline Dry matter \% & $25.43 \pm 0.65$ & $25.02 \pm 0.39$ & $25.13 \pm 0.69$ & $24.97 \pm 0.55$ \\
Crude protein (CP) \% & $63.23 \pm 0.37$ & $64.73 \pm 0.77$ & $64.11 \pm 0.88$ & $65.11 \pm 0.58$ \\
Ether extract ( EE) \% & $18.48 \pm 0.45$ & $17.90 \pm 0.55$ & $18.15 \pm 0.57$ & $17.82 \pm 0.48$ \\
Ash content \% & $18.29 \pm 0.11$ & $17.37 \pm 0.17$ & $17.74 \pm 0.15$ & $17.02 \pm 0.21$ \\
*Gross energy ( Kcal /Kg) & 5319 & 5349 & 5337 & 5287 \\
\hline
\end{tabular}

* All values are mean of triplicate feeding groups.

*Gross energy (Kcal /Kg) was estimated according to Jobling, (1983). Using the factor 5.65, 9.45 and 4 for crude protein, ether extract and carbohydrate, respective

Results of Table (6) demonstrate the effect of different protein sources of diets incorporated with LAB on biochemical freshness tests of Nile tilapia (O. niloticus). After the end of the trial, the $\mathrm{pH}$ values of tilapia muscle ranged between 5.78-5.90 in all treatments compared with control (6.10). The $\mathrm{pH}$ value can be used as a good indicator for the evaluation of fish freshness and quality, mainly due to its influence on texture, water holding capacity, resistance of microbial growth and color of fish flesh as reviewed by Hultin (1985). Total volatile bases nitrogen (TVB-N) content ranged from $12.4(\mathrm{mg} / 100 \mathrm{~g})$ in group of fish fed on diet plant protein to $15.2(\mathrm{mg} / 100 \mathrm{~g})$ in group of fish fed diet animal protein, while it was $14.90(\mathrm{mg} / 100 \mathrm{~g})$ of control sample. TVB-N content contains mainly of ammonia, (mono and di), and trimethylamine which occur normally after death of fish and due to the effect of microbiological activity on fish tissue. Based on analysis of variance, these results are not significantly different $(\mathrm{P} \leq 0.05)$. These results are in agreement with those reported by Shekib (1989). Trimethylaylamine nitrogen (TMA-N) content ranged between $0.74-0.78 \mathrm{mg} / 100 \mathrm{~g}$ in all treatments while it was $0.70 \mathrm{mg} / 100 \mathrm{~g}$ in control sample with non-significant differences. The TMA-N in fish tissues is an accepted measure of detritions; being good, test as quality indicator for fish and fishery products (Tonogai et al., 1984). Rodrigusez et al. (1999) reported that the levels of TMA-N depend on species, age, season, muscle type and diet of fish.

Table (6): Effect of different protein sources on quality criteria (means \pm SE) of Nile tilapia (O.niloticus) muscles.

\begin{tabular}{lcccc}
\hline \multirow{2}{*}{ Freshness tests } & & \multicolumn{3}{c}{ Different protein sources } \\
\cline { 3 - 5 } & Control & Animal & Plant & Combined \\
\hline pH value & $6.10 \pm 0.01$ & $5.78 \pm 0.02$ & $5.90 \pm 0.02$ & $5.90 \pm 0.01$ \\
$*$ TVBN $(\mathrm{mg} \backslash 100 \mathrm{~g})$ & $14.90 \pm 0.98$ & $15.2 \pm 1.97$ & $12.4 \pm 1.11$ & $14.8 \pm 1.14$ \\
$* *$ TMAN $(\mathrm{mg} \backslash 100 \mathrm{~g})$ & $0.70 \pm 0.03$ & $0.78 \pm 0.02$ & $0.74 \pm 0.01$ & $0.75 \pm 0.02$ \\
$* * *$ TBARS $(\mathrm{mg} \mathrm{MA} \mathrm{kg})$ & $0.45 \pm 0.01$ & $0.64 \pm 0.02$ & $0.59 \pm 0.01$ & $0.46 \pm 0.01$ \\
\hline
\end{tabular}

Values indicate mean $\pm S E(n=3)$., $* T V B-N$ : Total volatile basic nitrogen, $* * T M A-N$ : Trimethylamine nitrogen, $* * * T B A R S:$ thiobarbituric acid reactive substances.

So in the present study there is no effect of protein sources and LAB on TMA content. Thiobarbituric acid (TBA) value is considered as an indicator for the amount of Malonaldhyde (MAD) which is the most predominant secondary oxidation products of feed lipids hence it is considered a good criterion for quality assurance the extent of the secondary oxidation of edible lipids during processing (Green and Cumuz, 1982). In this study, TBA values (Table 6) ranged between $0.46-0.64 \mathrm{mg} \mathrm{MA} / \mathrm{kg}$ sample, while it was $0.45 \mathrm{mg}$ $\mathrm{MA} / \mathrm{kg}$ of control. Results indicated that TBA values in muscles of fish feed combined protein diet were lower $(0.46 \mathrm{mg} \mathrm{MA} / \mathrm{kg})$ than other one and it was similar of control (0.45 mg MA $/ \mathrm{kg}$ sample). The Egyptian Standard Specification (EOS, 1998) recommended that both TVB and TMA in fresh fish should not exceeding 30 and $5 \mathrm{mg} / 100 \mathrm{~g}$, respectively, and $10 \mathrm{~g} \mathrm{MAD} / \mathrm{kg}$ for (TBA) value. In general, the present results are localized with those finding by Abo-Taleb and Ibrahim (2002); Ibrahim and Desouky (2008); EL-Sherif 


\section{Hassanen et al.}

(2008); Ibrahim et al. (2008) and Abdallah (2013) who mentioned that range of freshness tests of Tilapiaflesh were $\mathrm{pH} 6.01-7.21$; TVB $9.80-22.00 \mathrm{mg} / 100 \mathrm{~g}$; TMA $0.52-1.27 \mathrm{mg} / 100 \mathrm{~g}$ and $0.042-4.29 \mathrm{mg} \mathrm{MDA} / \mathrm{kg}$ sample.

\section{CONCLUSION}

It could be concluded that the inoculated fish diets by metabolites improved the growth rate, chemical composition and quality criteria of Tilapia fish flesh compared with control sample and this leads to extend shelf-life for these fish.

\section{REFERENCES}

Abd El-Hamid, A.M.; F.F. M.Khalil and M.A.A. Seden (2000). Possibility of using dried live yeast and lactosac in Nile tilapia fingerlings diets. J. Agric. Sci. Mansoura Univ., 25: 4905-4911.

Abdalla, Sh.S. (2013). Studies on chemical and microbiological contaminates in some fish species and the influence of some cooking and processing methods on these contaminants. M.Sci. thesis, Fac. of Agric. Cairo Univ., Egypt.

Abdel-Hakim, N.F.; A.A. Al-Azab and H.A. Abo-State (2006). Growth performance of mono sex Nile tilapia (Oreochromisniloticus) fry as affected by dietary supplementations of some probiotics. Egypt. J. of Appl. Sci., 214 B.

Abo-State, H.A. (2005). Effect of using some probiotic on performance and immune response of Nile tilapia fingerlings. Ph. D. Thesis, Fac. Agric. Cairo Univ., Egypt.

Abo-Taleb, M. and S.M. Ibrahim (2002). Relationship between freshness degree of Nile bolti fish and quality of processed products. Annals of Agric. Sci. Moshtohor, 40 (3): 1571-1582.

Al-Souti, A.; J. Al-Sabahi; B. Soussi and S. Goddard (2012). The effects of fish oil-enriched diets on growth, feed conversion and fatty acid contents of red hybrid tilapia, Oreochromis sp. Food chemistry, 133: 723727.

AOAC (2000). Association of official analytical methods. Official Methods of Analysis. 16 ${ }^{\text {th }}$ ed. Arlington, Virginia. USA.

APHA (1992). Standard Methods for the Examination of water and waste water. American Public Health Association. Washington.

Blauth, D.J.; M. Chareinski and H. Drelie (1963). Anew rapid method for determining tryptophan. Anal. Chem., 96-99.

Bogut, I.; Z. Milakovic; Z. bukvic; S. Brkic and R. Zimmer (1998). Influence of probiotic (Streptococcus faecium M 74) on growth and content of intestinal microflora in carp (Cyprinuscarpio). Zivocisnavyroba., 43: 231-235.

Bone, Q. and N.B. Marshal (1982). Biology of fish. Blackie, Glasgow, 253pp.

Bonesteroo, M.H.; J.C. Dewit; B.J.M. Kusters and P.M. Rornbouts (1993). Inhibition of the growth of yeasts in fermented salad. Inter. J. of Food Microbiol., 17: 311-320.

Bullerman, L.B. (1977). Incidence and control of mycotoxin producing molds in domestic and imported cheeses. Annales de la nutrition et de 1" alimenation, 31: 435-46.

Chang, C.I. and W.Y. Liu (2002). An evaluation of tow probiotic bacterial strains, Enterococcus faeciumSF 68 and Bacillus touoi for reducing edwardsiellosis in cultured European Eel, Anguilla anguillaL., J. of Fish Dis., 25: 311.

Dalie, D.K.D.; A.M. Deschamps and F. Richard-Forget (2009). LAB-Potential for control of mould growth and mycotoxins. A review. Food control, 21: 370-380. 
de Man, J.D.; Rogosa, M.; Sharpe, M.E. (1960). A Medium for the Cultivation of Lactobacilli. J Appl Bact., 23: 130-135.

Eid, A.H. and K.A. Mohamed (2008). Effect of using probiotic as growth promoters in commercial diets for mono sex Nile tilapia (Oreochromis niloticus) fingerlings $8^{\text {th }}$ International symposium of Tilapia in Aquaculture. 241.

El-Ziney, M.G. and J.M. Debevere (1998). The effect of reuterin on Lesteriamonocytogenes and E. coli O157: H7 in milk and cottage cheese. J. of Food Protection, 61: 1275-1280.

EOS (1998). Egyptian Organization for Standardization. Final Report: Egypt: A Review of Selected Egyptian Organization for Standardization (EOS) Food Standards with Respect to International Forms. Frozen fish. 26 March, 1998. Pp: 176 - 179.

Filtenborg, O.; J.C. Frised and U. Thrane (1996). Moulds in food spoilage. Inter. J. Food Microbiol., 33: 85102.

Forgecs, J. and W.T. Carll (1962). Mycotoxicoses. Adv. Vet. Sc., 7: 273.

Fowler, L.G. (1980). Substitution of soybean and cottonseed products for fish meal in diets fed to Chinook and Coho Salmon. Prog. Fish Cult., 42: 86-91.

Green, B. E. and T.H. Cumuze (1982). Relationship between TBA numbers and in experienced panelist assess of oxidized flavor in cooked beef. J. Food Sci., 47: 52-58.

Hajen, W.; D. Higgs; R. Beames and B. Dosanjh (1993). Digestibility of various feedstuffs by post-juvenile Chinook Salmon (Oncorhynchustshawytscha) in sea water. 2. Measurements of digestibility. Aquaculture, 112: 333-348.

Hassanen, G.D.I. (1998). Lupin seed meal compared with soybean meal as partial substitutes for fish meal in gilthead sea bream (Sparusaurata) Diets. J. Agric. Sci. Mansoura Univ., 23 (1): 141-154.

Hassanen, G.D.I. (1997). Effect of diet composition and protein level on growths body composition and cost of production of gilthead sea bream (Sparusaurata). The first Scientific of the Egyptian Soc. For the development of fish Res. and Human health. Future prospects of fisheries resources in Egypt. EL-Arish, North Sinai, Egypt.

Hultin, H.D. (1985). Characteristics of muscle tissue. Food chemistry, (Fennema, O. R.ed) marcel Deker Inc., New York and Basel, P 925.

Ibrahim, A.A. (1974). Chemical, bacteriological and technological studies on fish protein concentrates. Ph.D. Thesis, Fac. of Agri., Cairo Univ., Egypt.

Ibrahim, S.M. and S.G. Desouky (2008). Effect of antimicrobial metabolites produced by lactic acid bacteria (LAB) on quality aspects of frozen tilapia (Orpochromisniloticus) fillets. World Journal of Fish and Marine Sciences, 1(1): 40-45.

Ibrahim, S.M.; K.A.Sh. Shalloof and H.M. Salama (2008). Effect of environmental condition of Abu-Zable Lake on some biological, histological and quality aspects of fish. Global Veterinaria. 2(5): 257-270.

Jobling, M. (1983). A short review and critique of methodology used in fish growth and nutrition. J. Fish Biol., 23: 685 .

Keysami, M.A.; C.R. Saad; K. Sijam; H.M. Daud and A.R. Alimon (2007). Effect of Bacillus subtilis on growth development and survival of larvae Macrobrachiumresenbrgii (de man). Aquaculture Nutrition, 13 (2): 131.

Lavermicocca, P.; F. Valerio; A. Evidente; S. Lazzaroni; A. Corsetti and M. Gobetti (2000). Purification and characterization of novel antifungal compounds from the sourdough Lactobacillus plantarum strain 21B. Appl. Environ. Microbiol., 66: 4084-4090.

Lindgren, S.E. and W.J. Dobrogosz (1990). Antagonistic activities of lactic acid bacteria in food and feed fermentations. FEMS Microbiol. Rev. 87: 149-164. 


\section{Hassanen et al.}

Messens, W. and L.de Vuyst (2002). Inhibitory substances produced by Lactobacilli isolated from sourdoughs -A review. Int. J. Food Microbiol. 72: 31-43.

Muhialdin, B.J.; Z. Hassan and N. Saari (2013). Lactic Acid Bacteria in Biopreservation and the enhancement of Functional Quality of Bread, chapter 6. http://dx.doi.org/ 10.5772151626.

Pearson, D. (1991). The Chemical Analysis of Food. Churchill, New York, London, pp: 374-410.

Pitt, G.I. and A.D. Hocking (1999). Fungi and food spoilage. Champman and Hall, New York.

Robaina, L.; M.S. Izqierdo; F.J. Moyano; J. Socorro; J.M. Vergara; D. Moter; H. Fermandez-Placios (1995). Soybean and lupine seed meals as protein sources in diets for githeadseabream (Sparusaurata): nutritional and histological implications. Aquaculture, 130: 219-233.

Rodriguez, C.J.; I. Besteiro and C. Pascual (1999). Biochemical change in freshwater rainbow trout (Oncorhynchusmykiss) during chilled storage. J. Sci. Food. Agric., 79: 1473-1480.

Roselund, G. (1986). Comparison between unconventional protein and fish meal as a dietary nitrogen source for rainbow trout (Salmogairdnen): Effects on in vitro muscle protein synthesis. Dir, Skr. Ser. Emering 2: 193-200.

Santiago, C.B. and R.T. Lovell (1988). Amino acid requirement for growth of Nile tilapia. J. Nutr., 118: $1540-1546$

Shekib, L.A. (1989). Effect of ingredients and freezing on chemical and nutritional properties of silver carp sausage. Minia J. Agric. and Dev., 11(3): 1445-1460.

Sib, S.G.; V. Sukumaran and M. Oviy (2013). Potential probiotic Lb. plantarum VSG3 improves the growth, immunity and disease resistance of tropical freshwater fish, Labeotohita. Fish and shellfish immunology, volume 34, (2): 660-666.

Snedecor, G.W. and W.G. Cochran (1974). Statistical Methods. Iowa state - Univ., Press, Ames; Iowa, USA. $\left(7^{\text {th }}\right.$ printing, $6^{\text {th }}$ edition, 593pp.

Stiles, M.E. (1996). Bio preservation by Lactic acid bacteria. Antonie Van Leeuwenhoek, 70, 331.

Tongnuanchan, P.; S. Benjakul and T. Prodpran (2011). Role of lipid oxidation and pH on properties and yellow discoloration during storage of film from red tilapia (Oreochromisniloticus) muscle protein. Food hydrocolloids, 25, 426-433.

Tonogai, Y.; Y. Ito and M. Harada (1984). Determination of volatile amines and ammonia in raw fish and fish products by gas chromatography. J. Food. Hygienic. Soci. Japan., 25 (2): 149. 
تأثير بعض العلائق الملقحة بمستخلص بكتيريا Lactobacillus plantarum DSMZ 20191 على خصائص النمو ومعايير الجودة لسمك البلطى النيلى (Oreochromis niloticus)

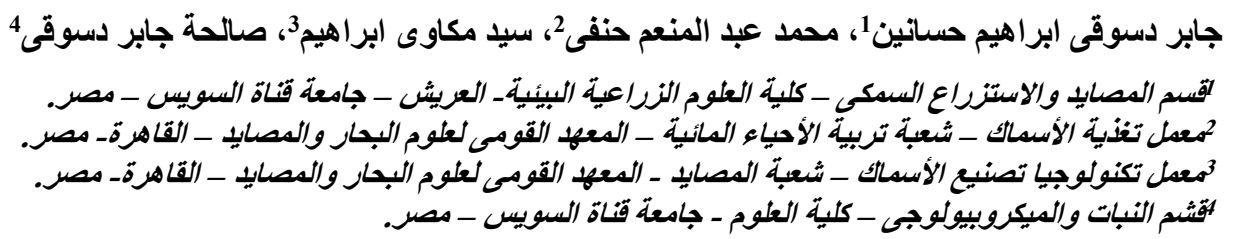

يهذف هذا البحث الى دراسة تأثير تغذية اصبعيات سكك البلطي النيلى بعلائق سمكية ذات مصادربروتينية مختلفة (نباتى، وحيوانى،

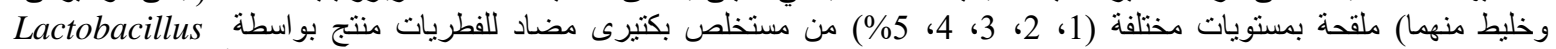
plantarum DSMZ 20191 فى نهاية فترة التغذية (180 يوما) مقارنة بالمعاملة الضابطة (الكنترول).

$$
\text { وقد أوضحت النتائج المتحصل عليها ما يلى: }
$$

كالظهر المستخلص البكتيرى بتركيز (5\%) فاعلية عالية ضد الفطريات الملوثة للأعلاف الحيو انية المصدر ومتوسطة في الأعلاف النباتية بينما

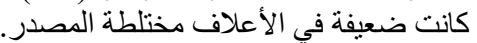

ـ ـ زيادة معدل نمو و وانخفاض معدل نفوف الافئ الصبعيات حيث أدت الأعلاف النباتية والمختلطة الى زيادة وزن الأصبعيات بينما ساهمت الأعلاف

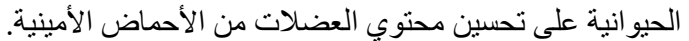

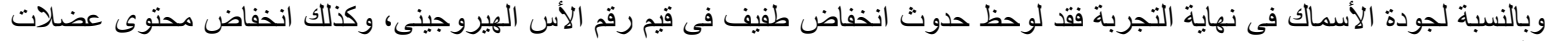

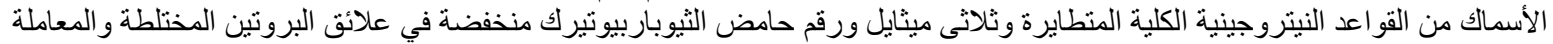
مقارنة بالغير معاملة مما يؤدى الى اطلالة فترة صلاحية هذه الأسماك. وبناءا على ماسبق توصى الدراسة بأهمية معاملة العلائق السمكية بمستخلصات بكتيرية آهنة مما لها من ناثير ايجابى على جودةد الأسماك الناتجة الأمر الذى يؤدى الى اطالة فترة صلاحيتها. 